\title{
The UV-visible absorption cross-sections of $\mathrm{IONO}_{2}$
}

\author{
J. C. Mössinger ${ }^{1}$, D. M. Rowley ${ }^{*}$, and R. A. $\operatorname{Cox}^{1}$ \\ ${ }^{1}$ Centre for Atmospheric Science, Chemistry Department, University of Cambridge, UK \\ *present address: Chemistry Department, University College London, UK
}

Received: 8 April 2002 - Published in Atmos. Chem. Phys. Discuss.: 12 June 2002

Revised: 9 August 2002 - Accepted: 29 August 2002 - Published: 10 September 2002

\begin{abstract}
The UV-visible absorption spectrum of gaseous $\mathrm{IONO}_{2}$ has been measured over the wavelength range 245$415 \mathrm{~nm}$ using the technique of laser photolysis with timeresolved UV-visible absorption spectroscopy. $\mathrm{IONO}_{2}$ was produced in situ in the gas phase by laser flash photolysis of $\mathrm{NO}_{2} / \mathrm{CF}_{3} \mathrm{I} / \mathrm{N}_{2}$ mixtures. Post flash spectra were deconvolved to remove contributions to the observed absorption from other reactant and product species. The resulting spectrum attributed to $\mathrm{IONO}_{2}$ consists of several overlapping broad absorption bands. Assuming a quantum yield of unity for $\mathrm{IONO}_{2}$ photolysis, model calculations show that during sunlit hours at noon, $53^{\circ} \mathrm{N}$, the first order solar photolysis rate coefficient ( $J$ value) for $\mathrm{IONO}_{2}$ is $4.0 \times 10^{-2} \mathrm{~s}^{-1}$.
\end{abstract}

\section{Introduction}

Iodine chemistry has been implicated in tropospheric ozone depletion since the 1980s (Chameides and Davis, 1980; Davis et al., 1996; Jenkin et al., 1985). Atmospheric iodine source gases are readily photolysed by sunlight, yielding iodine atoms. Iodine atoms react with ozone forming IO. Any subsequent reactions of IO forming an iodine atom lead to catalytic ozone loss. In competition, IO can be sequestered into reservoir species. One of the main gaseous reservoir species for iodine in the atmosphere is believed to be $\mathrm{IONO}_{2}$ (Chameides and Davis, 1980; Davis et al., 1996; Jenkin, 1992; Jenkin et al., 1985).

$\mathrm{IONO}_{2}$ is formed by the reaction of $\mathrm{IO}$ with $\mathrm{NO}_{2}$

$\mathrm{IO}+\mathrm{NO}_{2}+\mathrm{M} \rightarrow \mathrm{IONO}_{2}+\mathrm{M}$

The rate of formation of $\mathrm{IONO}_{2}$ in reaction (R1) is well known (De More et al., 1997) but the amount of $\mathrm{IONO}_{2}$

Correspondence to: J. C. Mössinger

(jcm34@hermes.cam.ac.uk) residing in the atmosphere and its consequent impact on the atmospheric chemistry depends on its loss processes. Gas phase $\mathrm{IONO}_{2}$ loss processes include photolysis, thermal decomposition and heterogeneous uptake.

$\mathrm{IONO}_{2}$ can be photolysed via two possible routes:

$$
\begin{aligned}
\mathrm{IONO}_{2}+h v & \rightarrow \mathrm{IO}+\mathrm{NO}_{2} \\
& \rightarrow \mathrm{I}+\mathrm{NO}_{3}
\end{aligned}
$$

However, no studies of the absorption cross-sections, the photolysis quantum yields or the products of $\mathrm{IONO}_{2}$ photolysis have been reported to date.

Thermal decomposition of $\mathrm{IONO}_{2}$ could proceed as in reaction (R3).

$\mathrm{IONO}_{2} \stackrel{\Delta}{\longrightarrow} \mathrm{IO}+\mathrm{NO}_{2}$

However, recent observations imply that reaction (R3) is a slow process at ambient temperature (Dillon, 2001; Allan and Plane, 2002).

A recent laboratory study has provided the first experimental evidence that $\mathrm{IONO}_{2}$ can be lost from the gas phase via a heterogeneous process (Holmes et al., 2001). It was shown that $\mathrm{IONO}_{2}$ is taken up efficiently by dry and frozen salt surfaces to form the di-halogens $\mathrm{IBr}$ and $\mathrm{ICl}$, which are then released back into the gas phase.

$\mathrm{IONO}_{2}$ has been synthesised in the laboratory in solution. However, $\mathrm{IONO}_{2}$ was found to be unstable and the first attempts to observe its ultraviolet-visible absorption spectrum failed (Schmeisser and Braendle, 1961). The absorption cross-sections for $\mathrm{IONO}_{2}$ in the UV-visible are essential, in order to evaluate the daytime atmospheric photolysis rate of $\mathrm{IONO}_{2}$ and the efficiency of the tropospheric ozone loss cycle involving $\mathrm{IONO}_{2}$.

Broske and Zabel (1998) attempted to measure the gas phase UV-visible absorption spectrum of $\mathrm{IONO}_{2}$ by photolysis of $\mathrm{I}_{2} / \mathrm{NO}_{2}$ mixtures in a large reaction chamber equipped 
Table 1. Concentrations used and generated during an experiment

\begin{tabular}{|c|c|c|}
\hline & Before laser photolysis & After laser photolysis/O atom reaction \\
\hline $\mathrm{N}_{2} /$ molecules $\mathrm{cm}^{-3}$ & $2.5 \times 10^{19}$ & $2.5 \times 10^{19}$ \\
\hline $\mathrm{NO}_{2} /$ molecules $\mathrm{cm}^{-3}$ & $4.0 \times 10^{15}$ & $3.9 \times 10^{15}$ \\
\hline $\mathrm{CF}_{3} \mathrm{I} /$ molecules $\mathrm{cm}^{-3}$ & $5.5 \times 10^{16}$ & $5.5 \times 10^{16}$ \\
\hline $\mathrm{CF}_{3} /$ molecules $\mathrm{cm}^{-3}$ & - & $7.5 \times 10^{13}$ \\
\hline $\mathrm{IO} /$ molecules $\mathrm{cm}^{-3}$ & - & $7.5 \times 10^{13}$ \\
\hline $\mathrm{NO} /$ molecules $\mathrm{cm}^{-3}$ & - & $8.5 \times 10^{13}$ \\
\hline $\mathrm{NO}_{3} /$ molecules $\mathrm{cm}^{-3}$ & - & $1.0 \times 10^{12}$ \\
\hline
\end{tabular}

for in situ spectroscopy. A diode array detector was used to monitor the UV-visible absorption spectrum. However, because of the low concentrations of $\mathrm{IONO}_{2}$ produced under their experimental conditions and the presence of strong absorbers such as $\mathrm{INO}_{2}$, produced by the reaction of iodine atoms from $\mathrm{I}_{2}$ photolysis with $\mathrm{NO}_{2}$, they were unable to retrieve the spectrum of $\mathrm{IONO}_{2}$. Nevertheless, the UV-visible absorption spectrum of gaseous $\mathrm{INO}_{2}$ was reported (Atkinson et al., 2000).

In order to avoid the effects of complicating chemistry involving iodine atoms produced in the IO source reactions, as well as the effects of secondary chemistry, a pulsed laser photolysis system and a photochemical source of IO with no initial iodine atom production $\left(\mathrm{NO}_{2} / \mathrm{CF}_{3} \mathrm{I}\right)$ was used in this study. We report here, for the first time observation of a gas phase ultraviolet-visible spectrum attributed to $\mathrm{IONO}_{2}$. The results were used to calculate the atmospheric photolysis rates of $\mathrm{IONO}_{2}$, and the atmospheric chemistry of $\mathrm{IONO}_{2}$ is discussed briefly.

\section{Experimental}

The $\mathrm{IONO}_{2}$ absorption spectrum was obtained using the technique of laser flash photolysis with UV absorption spectroscopy, utilising a CCD detection system. The apparatus has been described in detail elsewhere (Rowley et al., 1996), therefore only a brief description is given here.

During an experiment, gases were flowed slowly and continuously through a $98.2 \mathrm{~cm}$ long cylindrical quartz cell kept at a total pressure of 760 Torr. Reactions were initiated in the cell using a pulsed excimer laser beam passed longitudinally along the cell. Concentrations of reactant and product gases in the cell were monitored using UV-vis absorption spectroscopy. The analysis light beam from a xenon arc lamp was passed through the cell, counter propagating the laser beam, and focused onto the entrance slit of a $0.25 \mathrm{~m}$ focal length astigmatic Czerny-Turner spectrograph fitted with three interchangeable diffraction gratings ruled at 150, 300 and 600 grooves $/ \mathrm{mm}$. In order to protect the spectrograph and detector from impinging reflected laser light a narrow band filter was used in the $350 \mathrm{~nm}$ region. Wavelength resolved analysis light from the spectrograph was then imaged across the top 30 rows of a CCD detector, to record spectra. Signal (charge) transfer then enabled recording of sequential spectra, which were acquired before, during and after photolysis.

A $\mathrm{NO}_{2} / \mathrm{CF}_{3} \mathrm{I} / \mathrm{N}_{2}$ chemical system was employed to generate $\mathrm{IONO}_{2}$ via the following reaction scheme:

$$
\begin{aligned}
& \mathrm{NO}_{2}+h v \rightarrow \mathrm{NO}+\mathrm{O}\left({ }^{3} \mathrm{P}\right) \\
& \mathrm{O}\left({ }^{3} \mathrm{P}\right)+\mathrm{CF}_{3} \mathrm{I} \rightarrow \mathrm{CF}_{3}+\mathrm{IO} \\
& \mathrm{IO}+\mathrm{NO}_{2}+\mathrm{M} \rightarrow \mathbf{I O N O}_{2}+\mathbf{M} \\
& \mathrm{CF}_{3}+\mathrm{NO}_{2} \rightarrow \mathrm{CF}_{2} \mathrm{O}+\mathrm{FNO} \\
& \text { net }: 3 \mathrm{NO}_{2}+\mathrm{CF}_{3} \mathrm{I} \rightarrow \mathrm{CF}_{2} \mathrm{O}+\mathrm{FNO}+\mathbf{I O N O}_{2}
\end{aligned}
$$

The reaction was initiated using $351 \mathrm{~nm} \mathrm{XeF}$ excimer laser photolysis of $\mathrm{NO}_{2}$ to form $\mathrm{O}\left({ }^{3} \mathrm{P}\right)$ (DeMore et al., 1997). $\mathrm{N}_{2}$ (Messer, 99.996\%), 2000 ppm $\mathrm{NO}_{2}$ in $\mathrm{N}_{2}$ (Messer) and $\mathrm{CF}_{3} \mathrm{I}$ (Fluorochem, 99\%) were used as supplied. Gas mixtures were flowed through the reaction cell at a total pressure of 760 Torr and at $298 \mathrm{~K}$ via mass flow controllers or ball flow meters (for $\mathrm{NO}_{2}$ in $\mathrm{N}_{2}$ ) and their concentrations (see Table 1 for concentrations used) were calculated from known calibrated flow rates. In a single experiment 1152 spectra were collected on the CCD with a clocking speed of $\sim 1 \mu \mathrm{s}$ per pixel. The actual time resolution was $\sim 15 \mu$ s resulting from exposure of 30 pixels of the array. Post flash absorbance spectra were calculated relative to preflash spectra using Beer's law ( $A=\ln$ (Ipreflash/Ipostflash)). Consequently observed absorbances show changes in absorption brought about by the laser flash and by subsequent chemistry over a period of $\sim 1 \mathrm{~ms}$. The total absorption spectrum of the gas mixture was recorded using a $150 \mathrm{~g} / \mathrm{mm}$ and a $300 \mathrm{~g} / \mathrm{mm}$ grating giving a $130 \mathrm{~nm}$ and a $65 \mathrm{~nm}$ wavelength coverage, respectively. In the $245-335 \mathrm{~nm}$ region the $150 \mathrm{~g} / \mathrm{mm}$ grating was used with a $50 \mu \mathrm{m}$ spectrograph entrance slit giving a resolution (fwhm) of $1.67 \mathrm{~nm}$. In the $385-415 \mathrm{~nm}$ region the $300 \mathrm{~g} / \mathrm{mm}$ grating was used with a $10 \mu \mathrm{m}$ entrance slit and a resolution (fwhm) of $0.55 \mathrm{~nm}$. In both cases time de- 
Table 2. Chemical reaction scheme used in the FACSIMILE model (Curtis and Sweetenham, 1987)

\begin{tabular}{|c|c|c|}
\hline Reaction & Rate coeff. $295 \mathrm{~K} / \mathrm{cm}^{-3}$ molecule $^{-1} \mathrm{~s}^{-1}$ & Reference \\
\hline $\mathrm{O}\left({ }^{3} \mathrm{P}\right)+\mathrm{NO}_{2} \rightarrow \mathrm{NO}+\mathrm{O}_{2}$ & $1.10 \times 10^{-11}$ & (DeMore et al., 1997) \\
\hline $\mathrm{O}\left({ }^{3} \mathrm{P}\right)+\mathrm{NO}_{2} \rightarrow \mathrm{NO}_{3}$ & $4.20 \times 10^{-12}$ & (DeMore et al., 1997) \\
\hline $\mathrm{O}\left({ }^{3} \mathrm{P}\right)+\mathrm{CF}_{3} \mathrm{I} \rightarrow \mathrm{CF}_{3}+\mathrm{IO}$ & $1.10 \times 10^{-11}(* 0.85)$ & (Addison, et al., 1979) \\
\hline $\mathrm{NO}_{2}+\mathrm{CF}_{3} \rightarrow \mathrm{CF}_{2} \mathrm{O}+\mathrm{FNO}$ & $1.53 \times 10^{-11}$ & (Pagsberg et al., 1998) \\
\hline $\mathrm{NO}+\mathrm{CF}_{3} \rightarrow \mathrm{CF}_{3} \mathrm{NO}$ & $1.89 \times 10^{-11}$ & (Ley et al., 1995) \\
\hline $\mathrm{CF}_{3}+\mathrm{CF}_{3} \rightarrow \mathrm{C}_{2} \mathrm{~F}_{6}$ & $8.32 \times 10^{-12}$ & (Rossi and Golden, 1979) \\
\hline $\mathrm{IO}+\mathrm{IO} \rightarrow 2 \mathrm{I}+\mathrm{O}_{2}$ & $8.60 \times 10^{-11}(* 0.7)$ & (Bloss et al., 2001) \\
\hline $\mathrm{IO}+\mathrm{IO} \rightarrow \mathrm{OIO}+\mathrm{I}$ & $8.60 \times 10^{-11}(* 0.3)$ & (Bloss et al., 2001) \\
\hline $\mathrm{O}\left({ }^{3} \mathrm{P}\right)+\mathrm{IO} \rightarrow \mathrm{O}_{2}+\mathrm{I}$ & $1.20 \times 10^{-10}$ & (DeMore et al., 1997) \\
\hline $\mathrm{IO}+\mathrm{NO}_{2} \rightarrow \mathrm{IONO}_{2}$ & $9.00 \times 10^{-12}$ & (DeMore et al., 1997) \\
\hline $\mathrm{I}+\mathrm{NO}_{2} \rightarrow \mathrm{INO}_{2}$ & $7.50 \times 10^{-12}$ & (DeMore et al., 1997) \\
\hline $\mathrm{I}+\mathrm{NO} \rightarrow \mathrm{INO}$ & $4.50 \times 10^{-13}$ & (DeMore et al., 1997) \\
\hline $\mathrm{IO}+\mathrm{NO} \rightarrow \mathrm{I}+\mathrm{NO}_{2}$ & $2.20 \times 10^{-11}$ & (DeMore et al., 1997) \\
\hline $\mathrm{I}+\mathrm{INO}_{2} \rightarrow \mathrm{I}_{2}+\mathrm{NO}_{2}$ & $8.32 \times 10^{-11}$ & (v.d. Bergh and Troe, 1976) \\
\hline $\mathrm{I}+\mathrm{NO}_{3} \rightarrow \mathrm{IO}+\mathrm{NO}_{2}$ & $4.50 \times 10^{-10}$ & (Chambers et al., 1992) \\
\hline
\end{tabular}

pendent spectral information from up to three experiments were averaged to increase the signal to noise ratio.

Under the conditions chosen (Table 1) numerical models show that the chemistry of IO and $\mathrm{CF}_{3}$ dominates, as $\mathrm{O}\left({ }^{3} \mathrm{P}\right)$ reacts mainly $(93 \%)$ with $\mathrm{CF}_{3} \mathrm{I}$. In addition, only small amounts of $\mathrm{NO}$ are expected (from $\mathrm{NO}_{2}$ photolysis and the $\mathrm{O}\left({ }^{3} \mathrm{P}\right)+\mathrm{NO}_{2}$ reaction $\left.(7 \%)\right)$ and $\mathrm{I}$ atom production from the reaction $\mathrm{IO}+\mathrm{NO} \rightarrow \mathrm{I}+\mathrm{NO}_{2}$ is consequently unimportant. Thus, only small amounts of $\mathrm{INO}_{2}$ via reaction $\mathrm{I}+\mathrm{NO}_{2}+\mathrm{M} \rightarrow \mathrm{INO}_{2}+\mathrm{M}$ are formed. $\mathrm{IONO}_{2}$ is expected to be the only major iodine containing product formed under the experimental conditions used, as the reaction of $\mathrm{NO}_{2}$ with IO dominates over other possible reactions with IO. Thus, the $\mathrm{IONO}_{2}$ spectrum can in principle be obtained from the experimental spectrum, after subtraction of the absorption due to $\mathrm{CF}_{2} \mathrm{O}$ and $\mathrm{FNO}$ formed via reaction (R6) and addition of absorbance due to $\mathrm{NO}_{2}$ and $\mathrm{CF}_{3} \mathrm{I}$ consumed in reactions (R4) and (R5), respectively. However, it should be noted that the yield for reaction (R5) is 0.85 (Gilles et al., 1996). The identity of the remaining reaction channels is unknown (Gilles et al., 1996). Other products that could be formed via reaction (R5) such as IF or $\mathrm{CF}_{3} \mathrm{IO}$ could also contribute to the overall absorption spectrum obtained. However, since their absorption cross-sections have not been reported to date it is not possible to correct for their contribution to the overall absorption. Other known secondary and side reactions that occur were taken into account by using the numerical integration package FACSIMILE (Curtis and Sweetenham, 1987) to model the post flash chemistry in order to calculate the final product distribution. Details of the chemical reaction scheme used are listed in Table 2. The contribution of secondary products including $\mathrm{INO}_{2}$ will be discussed in the results and discussion section below. Spectra were not recorded below
$245 \mathrm{~nm}$ or between $335-385 \mathrm{~nm}$, due to low light levels of the analysis light beam in these regions, the latter due to the attenuation by the laser beam filter in the $350 \mathrm{~nm}$ region. The overall error on the $\mathrm{IONO}_{2}$ cross-sections including the uncertainty due to the unknown reaction channels mentioned above was estimated to be $25 \%$. The chemical mechanism adopted in the FACSIMILE model could not be fully tested, as all the products could not be diagnosed using our detection method and the time resolution of the experiment $(\sim 15 \mu \mathrm{s})$ did not allow the kinetics of product formation to be followed. The estimated error of $25 \%$ excludes possible systematic errors that could result from errors in the chemical mechanism used in the FACSIMILE model.

\section{Results and discussion}

The absorption spectrum recorded in the short wavelength region $(245-335 \mathrm{~nm})$ of the spectrum (Fig. 1), i.e. the absorbance calculated relative to pre-laser intensities, represents the change in absorption due to the overall chemical reaction initiated by the laser flash. In the analysis it was assumed that only the 5 principal species $\left(\mathrm{NO}_{2}, \mathrm{CF}_{3} \mathrm{I}, \mathrm{FNO}\right.$, $\mathrm{CF}_{2} \mathrm{O}$ and $\mathrm{IONO}_{2}$ ) contribute to this absorption. Thus a negative change in absorption results from $\mathrm{NO}_{2}$ and $\mathrm{CF}_{3} \mathrm{I}$ consumption and a positive change in absorption due to $\mathrm{IONO}_{2}$, $\mathrm{CF}_{2} \mathrm{O}$ and $\mathrm{FNO}$ production make up the observed spectrum. The post flash spectrum obtained was reproducible and remained constant over the time-scale of the spectral acquisition (the photolysed gas flowed out of the cell over a period of 10-15 s). The total absorption spectrum measured and the absorption spectrum of $\mathrm{IONO}_{2}$ can be expressed as shown in Eq. (1) and (2), respectively. 


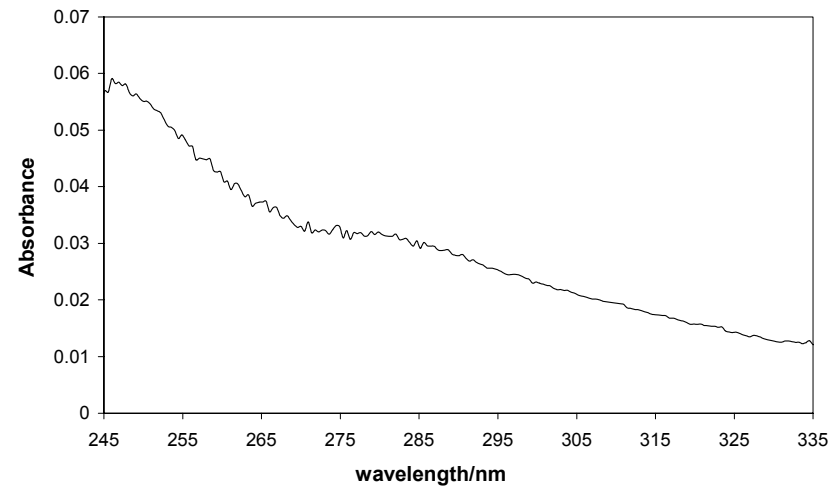

Fig. 1. Post flash absorption spectrum in the low wavelength region $(245-335 \mathrm{~nm})$ following flash photolysis of $\mathrm{NO}_{2}-\mathrm{CF}_{3} \mathrm{I}$ mixtures.

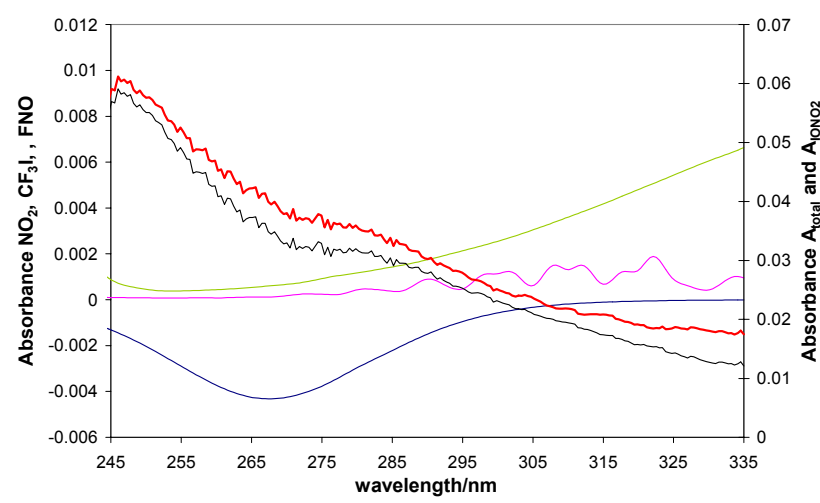

Fig. 2. Spectral stripping procedure in the low wavelength region $(245-335 \mathrm{~nm})$. Note changes in scale on the left and right hand axis. Black, pink, green and blue lines show the total absorption spectrum and absorption of $\mathrm{FNO}, \mathrm{NO}_{2}$, and $\mathrm{CF}_{3} \mathrm{I}$, respectively. The red spectrum is attributed to $\mathrm{IONO}_{2}$ after the stripping procedure. The contribution of $\mathrm{CF}_{2} \mathrm{O}$ is not shown as it only absorbs below $245 \mathrm{~nm}$.

$$
\begin{aligned}
& A_{\text {total }}=A_{\mathrm{IONO}_{2}}+A_{\mathrm{CF}_{2} \mathrm{O}}+A_{\mathrm{FNO}}-A_{\mathrm{NO}_{2}}-A_{\mathrm{CF}_{3} \mathrm{I}} \\
& A_{\mathrm{IONO}_{2}}=A_{\text {total }}-A_{\mathrm{CF}_{2} \mathrm{O}}-A_{\mathrm{FNO}}+A_{\mathrm{NO}_{2}}+A_{\mathrm{CF}_{3} \mathrm{I}}
\end{aligned}
$$

Thus $\mathrm{IONO}_{2}$ was found by spectral deconvolution. The contribution of each absorber to the total absorption at each wavelength recorded during an experiment is given by:

$A(\lambda)=\sigma_{i}(\lambda) \times l \times \Delta c_{i}$

where $A(\lambda)$ is the absorbance of a species $i$ at wavelength $\lambda, l$ is the pathlength of the reaction cell used $[\mathrm{cm}], \Delta c=$ change in concentration of species $i$ [molecules $\mathrm{cm}^{-3}$ ] and $\sigma_{i}(\lambda)=$ absorption cross-section of species $i$ at that wavelength [molecule $\mathrm{cm}^{-2}$ ].

In order to obtain the $\mathrm{IONO}_{2}$ spectrum the contribution of all species to the total absorbance change other than $\mathrm{IONO}_{2}$ has to be known. The concentrations of all species were calculated by simulating the post flash chemistry, and the main contributions $\left(\mathrm{NO}_{2}, \mathrm{CF}_{3} \mathrm{I}, \mathrm{FNO}, \mathrm{CF}_{2} \mathrm{O}\right)$ were determined from the known cross-sections of these species. Other possible contributors were $\mathrm{I}_{2}, \mathrm{OIO}, \mathrm{I}_{2} \mathrm{O}_{2}$, but the yields of these together with their known spectra were judged to be unimportant. Exceptions were the contribution of $\mathrm{CF}_{3} \mathrm{IO}$, for which we have no information about the cross-sections, and the contribution of $\mathrm{INO}_{2}$, which is discussed in detail below.

The absolute cross-sections of $\mathrm{CF}_{3} \mathrm{I}, \mathrm{FNO}$ and $\mathrm{CF}_{2} \mathrm{O}$ have been reported in the literature (DeMore et al., 1997) and were smoothed to the spectral resolution used for the present experiment $\left(\mathrm{CF}_{2} \mathrm{O}\right.$ only absorbs at wavelength shorter than $245 \mathrm{~nm}$ and its contribution to the overall absorption is thus not shown in Fig. 2). The change in concentration of each species after the laser flash is determined by the $\mathrm{O}$ atom concentration produced from $\mathrm{NO}_{2}$ photolysis in the flash and the stoichiometry of subsequent chemistry. In order to determine these concentration changes a kinetic model of the reaction system was constructed in the numerical integration package FACSIMILE (Curtis and Sweetenham, 1987). The model provided the simulated change in concentration of each species during an experiment for all given experimental conditions with the initial post flash $\mathrm{O}$ atom concentration being the only variable. In separate experiments $\mathrm{NO}_{2}$ was photolysed in the absence of $\mathrm{CF}_{3} \mathrm{I}$ and the initial $\mathrm{O}$ atom concentration was determined from the change in $\mathrm{NO}_{2}$ concentration following the flash, which was obtained from the measured change in absorption of $\mathrm{NO}_{2}$ and its cross-section. It was assumed that $[\mathrm{O}]=2 \Delta \mathrm{NO}_{2}$. Together with the known cross-sections, the contribution of each species to the absorption spectra was then subtracted from the overall post flash spectrum recorded as shown in Fig. 2 for the $245-335 \mathrm{~nm}$ region of the spectrum. The same procedure was applied to the data obtained in the longer wavelength region $(385-415 \mathrm{~nm})$ as shown in Fig. 3. However, in this wavelength region only $\mathrm{NO}_{2}$ absorbs significantly and thus the $\mathrm{NO}_{2}$ spectrum had to be subtracted from the total absorption spectrum. The fact that the structural features of $\mathrm{FNO}$ and $\mathrm{NO}_{2}$ do not appear to a significant extent in the final spectrum provides support for the deconvolution procedure used.

Secondary chemistry generates about $15 \%$ of $\mathrm{INO}_{2}$ compared to $\mathrm{IONO}_{2}$ in the laser flash. The cross-sections for $\mathrm{INO}_{2}$ are known (Atkinson et al., 2000) and together with its simulated concentration the contribution of $\mathrm{INO}_{2}$ to the total absorption spectrum recorded during an experiment was also subtracted. Figure 4 shows the $\mathrm{IONO}_{2}$ absorption spectrum obtained from subtracting the main components as described above together with the $\mathrm{INO}_{2}$ absorption spectrum and the final $\mathrm{IONO}_{2}$ absorption spectrum corrected for the contribution of $\mathrm{INO}_{2}$ (Atkinson et al., 2000). Subtraction of $\mathrm{INO}_{2}$ does not significantly change the shape of the $\mathrm{IONO}_{2}$ absorption spectrum and the change in the magnitude of the crosssections lies within the estimated uncertainty. The absorption cross-sections of $\mathrm{IONO}_{2}$ were then obtained assuming 


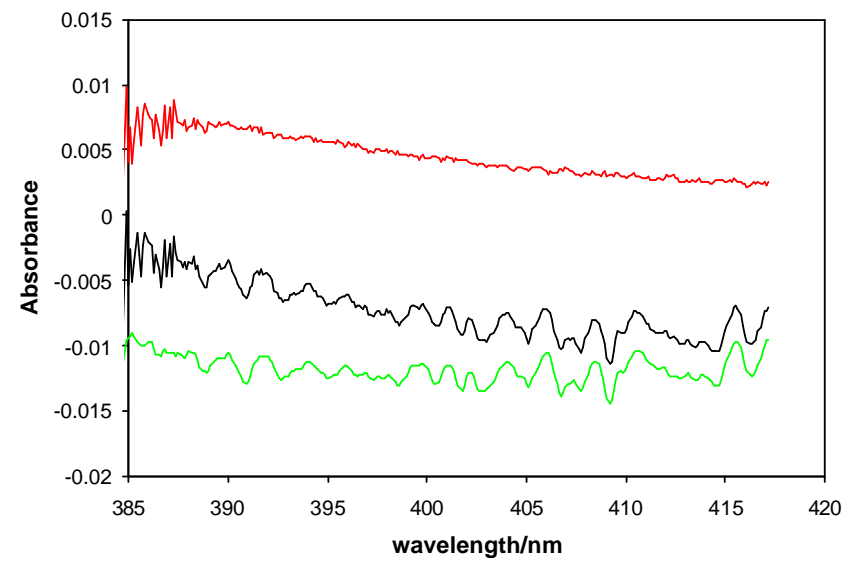

Fig. 3. Spectral stripping procedure in the high wavelength region (385-415 nm). Black, green and red lines show the total absorption spectrum, absorption of $\mathrm{NO}_{2}$ and $\mathrm{IONO}_{2}$ after the stripping procedure, respectively.

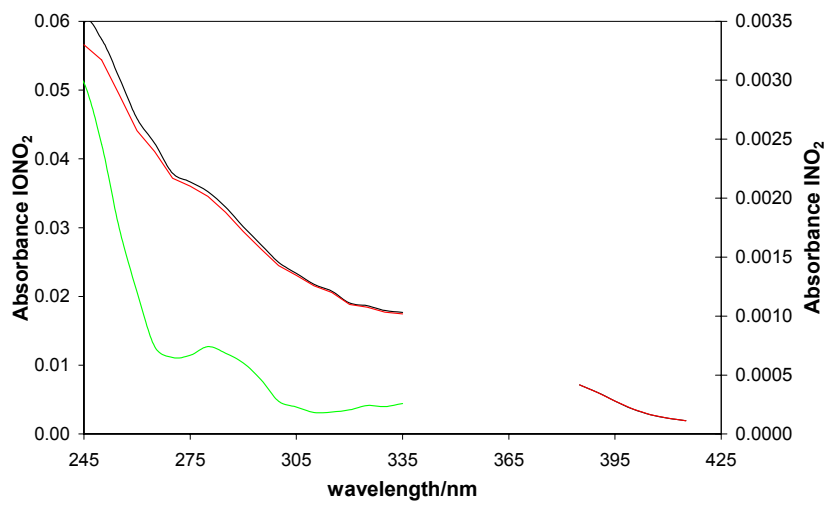

Fig. 4. Comparison of the absorption spectrum of $\mathrm{IONO}_{2}$ and $\mathrm{INO}_{2}$ generated during an experiment. Note changes in scale on the left and right hand axis. Black, green and red line show the spectrum originally assigned to $\mathrm{IONO}_{2}$ obtained from the initial deconvolution process, the absorbance due to $\mathrm{INO}_{2}$ generated following the laser flash, and the final $\mathrm{IONO}_{2}$ absorption spectrum after correction for the contribution of $\mathrm{INO}_{2}$, respectively.

that the remaining absorption was attributed to the simulated amount of $\mathrm{IONO}_{2}$ generated in the reaction.

The $\mathrm{IONO}_{2}$ absorption spectrum over the entire wavelength range of $245-415 \mathrm{~nm}$ was obtained by fitting the observed spectrum to three Gaussian functions. This enabled interpolation of the $\mathrm{IONO}_{2}$ absorption in spectral regions where absorbance could not be recorded. The resulting spectrum consists of a broad continuous absorption band as shown in Fig. 5. The $\mathrm{IONO}_{2}$ cross-sections are listed in Table 3. There is also a possibility of a contribution to the apparent $\mathrm{IONO}_{2}$ spectrum from formation of light scattering aerosol produced in the IO radical chemistry. A maximum potential contribution to the absorption from aerosol
Table 3. The absorption cross-sections of $\mathrm{IONO}_{2}$ at $298 \mathrm{~K}$

\begin{tabular}{cc}
\hline$\lambda / \mathrm{nm}$ & $10^{18} \sigma_{298} /$ molecule $\mathrm{cm}^{-2}$ \\
\hline 245 & 12.1 \\
250 & 11.7 \\
255 & 10.6 \\
260 & 9.46 \\
265 & 8.80 \\
270 & 7.97 \\
275 & 7.72 \\
280 & 7.41 \\
285 & 6.91 \\
290 & 6.31 \\
295 & 5.77 \\
300 & 5.25 \\
305 & 4.95 \\
310 & 4.62 \\
315 & 4.41 \\
320 & 4.04 \\
325 & 3.96 \\
330 & 3.80 \\
335 & 3.74 \\
340 & 3.60 \\
345 & 3.48 \\
350 & 3.34 \\
355 & 3.16 \\
360 & 2.94 \\
365 & 2.70 \\
370 & 2.42 \\
375 & 2.13 \\
380 & 1.84 \\
385 & 1.53 \\
390 & 1.30 \\
395 & 1.03 \\
400 & 0.780 \\
405 & 0.605 \\
410 & 0.496 \\
415 & 0.416 \\
\hline &
\end{tabular}

was calculated assuming all absorption at $\lambda=450 \mathrm{~nm}$ was due to aerosol extinction and that the attenuation at lower wavelength followed a $1 / \lambda^{4}$ functional dependence on wavelength (Cox and Coker, 1983). After subtraction of this component the lower curve in Fig. 6 was obtained which corresponds to minimum values for the $\mathrm{IONO}_{2}$ cross-sections. Examination of time resolved absorption spectra also show no evidence for time delayed aerosol growth for the first two experiments performed in a clean flow tube. After rapid formation of $\mathrm{IONO}_{2}$ the absorption remained constant over the whole time period of the experiment. Only after multiple experiments in the flow tube did we observe a time delayed increase in overall absorption with time, possibly due to the formation of aerosols, presumably from precursors formed in heterogeneous processes on the walls of the reaction cell. 


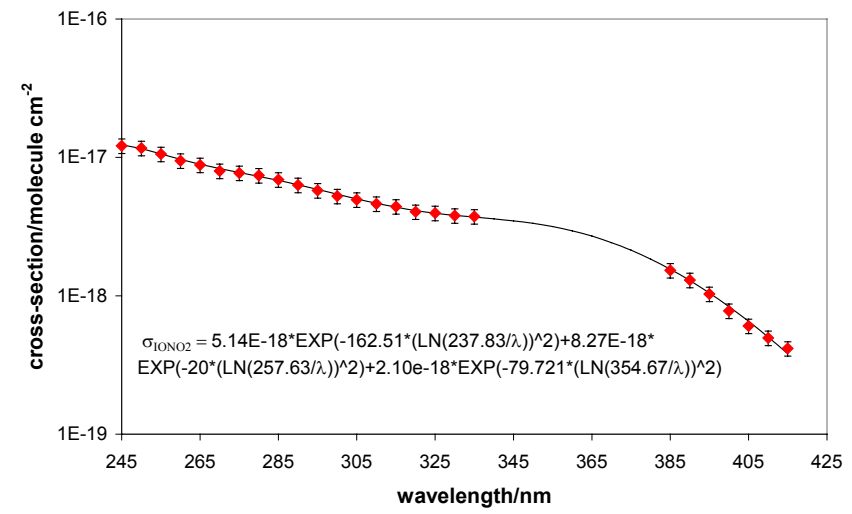

Fig. 5. Absorption cross-sections of $\mathrm{IONO}_{2}$. Red diamonds: data recorded in the $245-335 \mathrm{~nm}$ and in the $385-415 \mathrm{~nm}$ wavelength region. Black line: Fit to data.

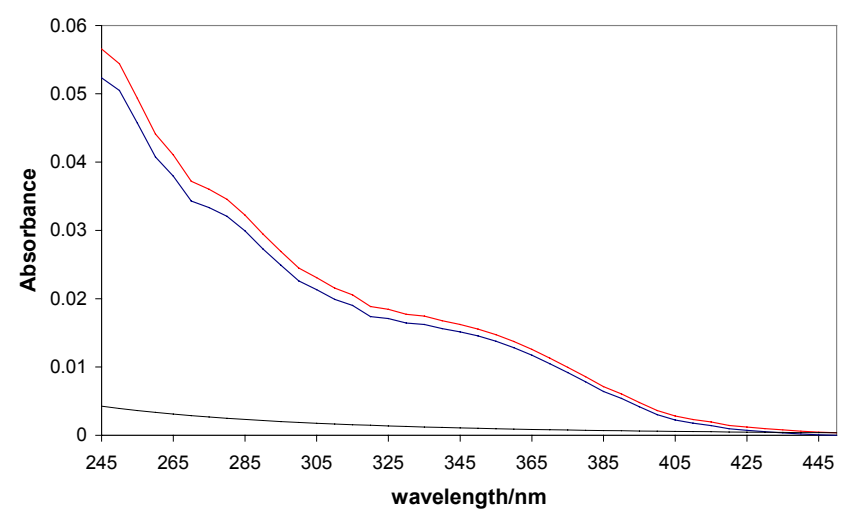

Fig. 6. Comparison of the absorption spectrum of $\mathrm{IONO}_{2}$ (red), the predicted absorption due to aerosol formation as a function of $1 / \lambda^{4}$ (black) and the contribution due to aerosol absorption subtracted from the original absorption spectrum of $\mathrm{IONO}_{2}$ (blue).

Figure 7 shows a comparison of the $\mathrm{IONO}_{2}$ absorption and the $\left(\mathrm{IONO}_{2}\right.$-aerosol) absorption with those of $\mathrm{ClONO}_{2}$ (Burkholder et al., 1994) and $\mathrm{BrONO}_{2}$ (Burkholder et al., 1995). All spectra show similar broad band absorption features. The absorption due to $\mathrm{IONO}_{2}$ is red shifted and is significantly more intense at all wavelengths than the chlorine and bromine analogues.

\section{Atmospheric implications}

The $\mathrm{IONO}_{2}$ absorption cross-sections recorded here were used to calculate the tropospheric solar photolysis rate of $\mathrm{IONO}_{2}$ using a photochemical box model (McFiggans et al., 2000). We assumed a quantum yield of unity for $\mathrm{IONO}_{2}$ photolysis throughout the absorption band. The resulting photolysis rate coefficient ( $J$-value) for $\mathrm{IONO}_{2}$ is shown in Fig. 8 as a function of time of day in the marine boundary layer, for July $53^{\circ} \mathrm{N}$ at Mace Head, Ireland, where mea-

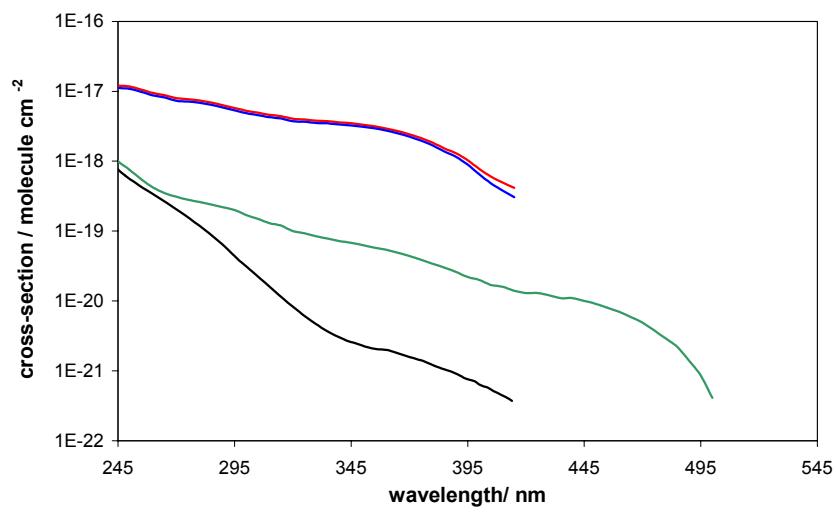

Fig. 7. Comparison of the absorption spectra of $\mathrm{ClONO}_{2}$ (black), $\mathrm{BrONO}_{2}$ (green), $\mathrm{IONO}_{2}$ (red) and $\left(\mathrm{IONO}_{2}\right.$-aerosol) contribution (blue).

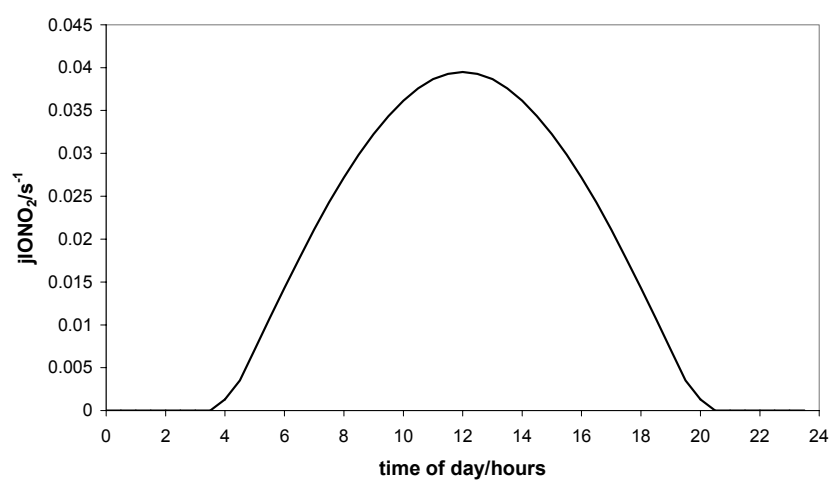

Fig. 8. $J$-values for $\mathrm{IONO}_{2}$ as a function of time of day in the marine boundary layer, for midsummer $53^{\circ} \mathrm{N}$ (Mace Head, Ireland, July 1997).

surements of atmospheric composition had taken place in 1997. The calculated photolytic lifetime of $\mathrm{IONO}_{2}$ under these conditions is less than one minute. At the same location and time, the surface to volume ratio $(S / V)$ of the fine fraction of the sea-salt aerosol present was determined to be $(6 \pm 1) \times 10^{-7} \mathrm{~cm}^{2} \mathrm{~cm}^{-3}$ with an effective particle radius of $2.5 \times 10^{-5} \mathrm{~cm}$ (McFiggans et al., 2000). Using these values, the lifetime of $\mathrm{IONO}_{2}$ with respect to heterogeneous uptake on sea-salt aerosols, $\tau_{\text {het }}[\mathrm{s}]$, was calculated to be $\sim 10 \mathrm{~h}$ using Eqs. (4) and (5) below, and assuming a reactive uptake coefficient of $\gamma=0.01$ (Holmes et al., 2001). Equation (4) assumes spherical geometry of the sea-salt particle. It also takes diffusion of $\mathrm{IONO}_{2}$ to the particle surface into account (Turco et al., 1989).

$$
\begin{aligned}
k_{\text {het }} & =\frac{0.25 \times \gamma \times \omega \times S / V}{(1+(3 \times \gamma \times r) /(4 \times \lambda))} \\
\tau_{\text {het }} & =\frac{1}{k_{\text {het }}}
\end{aligned}
$$


where $\omega=$ the average molecular speed of $\mathrm{IONO}_{2}$ at any given temperature $\left[\mathrm{cm} \mathrm{s}^{-1}\right], k_{\text {het }}=$ first order rate constant for loss of $\mathrm{IONO}_{2}$ on the aerosol $\left[\mathrm{s}^{-1}\right], \lambda=$ mean free path of a molecule in air at any given temperature and pressure $[\mathrm{cm}]$.

During daytime, solar photolysis is thus expected to be the major loss process for $\mathrm{IONO}_{2}$ and $\mathrm{IO}_{\mathrm{x}}$ is not lost from the gas phase. However, the reaction of $\mathrm{IONO}_{2}$ with sea-salt aerosol may become a significant loss process for $\mathrm{IONO}_{2}$ during night time. Uptake of $\mathrm{IONO}_{2}$ is expected to form the di-halogens ICl and IBr (Holmes et al., 2001), which are released into the gas phase during the night. At dawn, $\mathrm{IBr}$ and $\mathrm{ICl}$ are photolysed. Hence $\mathrm{IO}_{\mathrm{x}}$ would not be lost permanently from the gas phase via this reaction as suggested previously (Chatfield and Crutzen, 1990; Davis et al., 1996; Jenkin, 1992), and the uptake of $\mathrm{IONO}_{2}$ represents a route to liberation of bromide and chloride from sea-salt aerosols, as has been predicted by more recent modelling studies (McFiggans et al., 2000; Vogt et al., 1999). Thermal decomposition of $\mathrm{IONO}_{2}$ may also contribute to the night time loss of $\mathrm{IONO}_{2}$. However, recent observations have shown that the lifetime of $\mathrm{IONO}_{2}$ with respect to thermal decomposition at $298 \mathrm{~K}$ is approximately $6 \mathrm{~min}$ with a lower limit of $2.4 \mathrm{~min}$ (Allan and Plane, 2002).

Depending upon the photolysis product yields, photolysis of $\mathrm{IONO}_{2}$ could contribute directly to ozone destruction via the following reaction cycle:

$$
\begin{aligned}
& \mathrm{IO}+\mathrm{NO}_{2}+\mathrm{M} \rightarrow \mathrm{IONO}_{2}+\mathrm{M} \\
& \mathrm{IONO}_{2}+h v \rightarrow \mathrm{I}+\mathrm{NO}_{3} \\
& \mathrm{NO}_{3}+h v \rightarrow \mathrm{NO}+\mathrm{O}_{2} \\
& \mathrm{NO}+\mathrm{O}_{3} \rightarrow \mathrm{NO}_{2}+\mathrm{O}_{2} \\
& \mathrm{I}+\mathrm{O}_{3} \rightarrow \mathrm{IO}+\mathrm{O}_{2} \\
& \overline{2 \mathrm{O}_{3} \rightarrow 3 \mathrm{O}_{2}}
\end{aligned}
$$

However, it is important to note, that this cycle will not operate if the products of $\mathrm{IONO}_{2}$ photolysis are $\mathrm{IO}+\mathrm{NO}_{2}$. No studies of the photolysis products of $\mathrm{IONO}_{2}$ have been reported, and such studies are essential to elucidate further the role of atmospheric $\mathrm{IONO}_{2}$.

\section{Conclusions}

The UV-visible cross-sections of $\mathrm{IONO}_{2}$ have been determined over the wavelength ranges $245-335 \mathrm{~nm}$ and 385 $415 \mathrm{~nm}$. Both data sets were used to interpolate an $\mathrm{IONO}_{2}$ absorption spectrum over the wavelength range of 245$415 \mathrm{~nm}$. The resulting spectrum consists of several overlapping broad absorption bands. Based on the $\mathrm{IONO}_{2}$ absorption cross-section, the tropospheric solar photolysis rate coefficient of $\mathrm{IONO}_{2}$ has been calculated. This indicates that the photochemical lifetime of atmospheric $\mathrm{IONO}_{2}$ is less than one minute under most sunlit conditions and consequently that photolysis is the main loss process for gaseous $\mathrm{IONO}_{2}$. Thus, $\mathrm{IONO}_{2}$ is thus not expected to act as a stable reservoir of atmospheric iodine during daytime.

Acknowledgements. The authors thank William Bloss for help with the experimental system and Gordon McFiggans and Xin Yang for calculating the photolysis rate coefficients for $\mathrm{IONO}_{2}$. Many thanks to John Crowley for helpful comments on the manuscript. J. C. Mössinger would like to thank Girton College Cambridge for a Junior Research Fellowship. D. M. Rowley would like to thank NERC for the award of an Advanced Fellowship.

\section{References}

Allan, B. J. and Plane, J. M. C.: A study of the recombination of IO with $\mathrm{NO}_{2}$, and the stability of $\mathrm{INO}_{3}$ : implications for the atmospheric chemistry of iodine, J. Phys. Chem., in press, 2002.

Addison, M. C., Donovan, R. J., and Gamanay, J.: Reactions of $\mathrm{O}\left(2^{1} \mathrm{D}_{2}\right)+\mathrm{O}\left(2^{3} \mathrm{P}_{\mathrm{j}}\right)$ with halogenomethanes, Farad. Discuss. Chem. Soc., 286-293, 1979.

Atkinson, R., Baulch, D. J., Cox, R. A., Hampson, Jr., R. F., Kerr, J. A., and Troe, J.: Evaluated Kinetic and Photochemical Data for Atmospheric Chemistry, Supplement VIII, J. Phys. Chem. Ref. Data, 167-266, 2000.

Bloss, W. J., Rowley, D. M., Cox, R. A., and Jones, R. L.: Kinetic and products of the IO self reaction, J. Phys. Chem. A, 105, 7840-7854, 2001

Burkholder, J. B., Ravishankara, A. R., and Solomon, S.: Temperature-dependence of the $\mathrm{ClONO}_{2}$ UV absorption spectrum, Geophys. Res. Lett., 21, 585-588, 1994.

Burkholder, J. B., Ravishankara, A. R., and Solomon, S.: UV visible and IR absorption cross-sections of $\mathrm{BrONO}_{2}$, J. Geophys. Res., 100, 16 793-16 800, 1995.

Broske, R. and Zabel, F.: The UV-visible absorption spectrum of $\mathrm{IONO}_{2}$, in: Laboratory Experiments of Iodine Chemistry in the Stratosphere-LEXIS, EC, Brussels, 1998.

Chambers, R. M., Heard, A. C., and Wayne, R. P.: Inorganic gasphase reactions of the nitrate radical: $\mathrm{I}_{2}+\mathrm{NO}_{3}$ and $\mathrm{I}+\mathrm{NO}_{3}$, J. Phys. Chem., 96, 3321-3331, 1992.

Chameides, W. L. and Davis, D. D.: Iodine: Its possible role in tropospheric photochemistry, J.Geophys. Res., 85, 7383-7393, 1980.

Chatfield, R. B. and Crutzen, P. J.: Are there interactions of iodine and sulfur species in marine air photochemistry, J. Geophys. Res., 95D, 22 319-22 341, 1990.

Cox, R. A. and Coker, G. B.: Absorption cross-section and kinetics of $\mathrm{IO}$ in the photolysis of $\mathrm{CH}_{3} \mathrm{I}$ in the presence of ozone, J. Phys. Chem., 87, 4478-4484, 1983.

Curtis, A. R. and Sweetenham, W. P.: FACSIMILE, AERE Harwell publication R 12805, Computer Science and Systems Division, Harwell Laboratory, Oxfordshire, UK, 1987.

Davis, D., Crawford, J., Liu, S., McKeen, S., Bandy, A., Thornton, D., Rowland, F., and Blake, D.: Potential impact of iodine on tropospheric levels of ozone and other critical oxidants, J. Geophys. Res., 101, 2135-2147, 1996.

DeMore, W. B., Sander, S. P., Golden, D. M., Hampson, R. F., Kurylo, M. J., Howard, C. J., Ravishankara, A. R., Colb, C. E., and Molina, M. J.: Chemical Kinetics and Photochemical Data 
for use in Stratospheric Modeling, Evaluation No 12. Pasadena, CA, Jet Propulsion Laboratory, 1997.

Dillon, T.: Ph.D. thesis, University of Leeds, UK, 2001.

Gilles, M. K., Turnipseed, A. A., Talukdar, R. K., Rudich, Y., Villalte, P. W., Huey, L. G., Burkholder, J. B., and Ravishankara, A. R.: Reactions of O (P-3) with alkyl iodides: Rate coefficients and reaction products, J. Phys. Chem., 100, 14 005-14 015, 1996.

Holmes, N. S., Adams, J. W., and Crowley, J. N.: Uptake and reaction of $\mathrm{HOI}$ and $\mathrm{IONO}_{2}$ on frozen and dry $\mathrm{NaCl} / \mathrm{NaBr}$ surfaces and $\mathrm{H}_{2} \mathrm{SO}_{4}$, Phys. Chem. Chem. Phys., 3, 1679-1687, 2001.

Jenkin, M. E.: The photochemistry of iodine containing compounds in the marine boundary layer, Technical Report AEA-EE-0405, Harwell Laboratory, Oxfordshire, UK, 1992.

Jenkin, M. E., Cox, R. A., and Candeland, D. E.: Photochemical aspect of tropospheric iodine behaviour, J. Atmos. Chem., 2, 359375, 1985.

Ley, L., Masanet, J., Canalp, F., and Lesclaux, R.: Kinetics of the association reactions of $\mathrm{NO}$ with the series of chlorofluoromethyl radicals $\mathrm{CF}_{\mathrm{X}} \mathrm{Cl}_{3-\mathrm{x}}$, J. Phys. Chem., 99, 1953-1960, 1995.

McFiggans, G., Plane, J. M. C., Allan, B. J., Carpenter, L. J., Coe, H., and O'Dowd, C.: A modelling study of iodine chemistry in the marine boundary layer, J. Geophys. Res.-Atmos., 105, 14 363-14369, 2000.
Pagsberg, P., Jodkowski, J. T., Ratajzak, E., and Sillesen, A.: Experimental and theoretical studies of the reaction between $\mathrm{CF}_{3}+$ $\mathrm{NO}_{2}$ at $298 \mathrm{~K}$, Chem. Phys. Lett., 286, 138-144, 1998.

Rossi, M. J. and Golden, D. M.: Rate of the decomposition of hexafluoroazomethane and the absolute rate of recombination of trifluoromethyl radical at higher temperatures, Int. J. Chem. Kinet., 11, 775-783, 1979.

Rowley, D. M., Harwood, M. H., Freshwater, R. A., and Jones, R. L.: A novel flash photolysis/UV absorption system employing charge-coupled device (CCD) detection: A study of the $\mathrm{BrO}+$ BrO reaction at $298 \mathrm{~K}$, J. Phys. Chem., 100, 3020-3031, 1996.

Schmeisser, M. and Braendle, K.: Halogennitrate und ihre Reaktionen, Angew. Chem., 73, 388-393, 1961.

Turco, R. P., Toon, O. B., and Hamill, P.: Heterogeneous physicochemistry of the polar ozone hole, J. Geophys. Res., 94, $16493-$ $16510,1989$.

van den Bergh, H. and Troe, J.: Kinetic and thermodynamic properties of INO $+\mathrm{INO}_{2}$ intermediate complexes in iodine recombination, J. Chem. Phys., 64, 736-748, 1976.

Vogt, R., Sander, R., Glasow von, R., and Crutzen, P. J.: Iodine chemistry and its role in halogen activation and ozone loss in the marine boundary layer: A model study, J. Atmos. Chem., 32, 375-395, 1999. 